\title{
Preliminary data on larval development of Caucasian cave-dwelling shrimp Troglocaris (Xiphocaridinella) kumistavi Marin, 2017 (Crustacea: Decapoda: Atyidae)
}

\section{Предварительные данные по Аичиночному развитию кавказской пещерной креветки Troglocaris (Xipbocaridinella) kumistavi Marin, 2017 (Crustacea: Decapoda: Atyidae)}

\author{
Ivan N. Marin ${ }^{1,2}$, Sergey Yu. Sinelnikov ${ }^{3}$ \\ Иван Н. Марин ${ }^{1,2}$, Сергей Ю. Синельников ${ }^{3}$
}

\footnotetext{
${ }^{1}$ A.N. Severtzov Institute of Ecology and Evolution of RAS, Moscow, 119071 Russia.

E-mail: coralliodecapoda@mail.ru,vanomarin@yahoo.com

${ }^{1}$ Институт проблем экологии и эволюции им. А.Н. Северцова РАН, Москва, 119071 Россия.

${ }^{2}$ Biological Department, Altai State University, Barnaul, 656049 Russia.

2 Биологический факультет, Алтайский государственный университет, Барнаул, 656049 Russia.

${ }^{3}$ I.D. Papanin Institute of Biology of Inland Waters of RAS, Yaroslavl Province, 152742 Russia. E-mail: sinelnikoff@yandex.ru

${ }^{3}$ Институт биологии внутренних вод им. И.Д. Папанина, Ярославская область, 152742 Россия.
}

KEY WORDS: Crustacea, Decapoda, Atyidae, Troglocaris, Xiphocaridinella, lipid reserves, stygobiotic, development, larvae, Caucasus.

КЛЮЧЕВЫЕ СЛОВА: Crustacea, Decapoda, Atyidae, Troglocaris, Xiphocaridinella, липидные запасы, стигобиоты, развитие, личинка, Кавказ.

ABSTRACT. Up to date, any characteristics of the development of stygobiotic Troglocaris shrimp larvae remained unknown. The article briefly describes the first case of finding of ovigerous females, larval development and the use of yolk lipid in larval nutrition of Caucasian cave-dwelling shrimp Troglocaris (Xiphocaridinella) kumistavi Marin, 2017 (Crustacea: Decapoda: Atyidae). Troglocaris larvae are planktonic and lecithotrophic, able to develop using the expense of egg yolk exclusively, without feeding. This trait allows shrimps of the genus Troglocaris completing metamorphosis in oligotrophic planktonless cave water reservoirs during the low water period, thus shrimp larvae are not washed away; however, alochtonic organics do not enter into caves during this period as well. Characteristics of larval development of $T$. kumistavi also make it possible to understand that these cave shrimps can reproduce only in large stable water reservoirs (underground lakes), and therefore spend much of the life cycle there, than in rivers or streams.

How to cite this article: Marin I.N., Sinelnikov S.Yu. 2017. Preliminary data on larval development of Caucasian cave-dwelling shrimp Troglocaris (Xiphocaridinella) kumistavi Marin, 2017 (Crustacea: Decapoda: Atyidae) // Arthropoda Selecta. Vol.26. No.4. P.297-302. doi: 10.15298/arthsel.26.4.03

РЕЗЮМЕ. Особенности развития личинок рода пещерных креветок Troglocaris оставались до последнего времени неизвестными В статье кратко представлено описание первой находки яйценосных самок, личиночного развития и использование желтка в развитии личинок пещерной креветки Troglocaris (Xiphocaridinella) kumistavi Marin, 2017 (Crustacea: Decapoda: Atyidae). Показано, что личинки Troglocaris являются планктонными и лецитотрофными, в течение всего периода развития способны развиваться исключительно за счет запасов яичного желтка, не питаясь. Данная особенность позволяет креветкам рода Troglocaris размножаться в олиготрофных, лишенных планктона, пещерных водоемах в период межени, когда уровень воды максимально низкий и личинки не вымываются; однако и аллохтонная органика в этот период в водоемы также не поступает. Особенности личиночного развития T. kumistavi также позволяют понять, что эти пещерные креветки могут размножаться лишь в крупных водоемах со стоячей водой (подземных озерах), а значит и проводят там большую часть жизненного цикла, нежели в подземных реках или ручьях, куда их, скорее всего, вымывает.

\section{Introduction}

Limitation and irregular supply of food is a major driving force for the evolution of cave animals [Vandel, 1965; Barr, 1968]. Subterranean animals, including shrimps, fishes and salamanders, are able to live without food for long periods, up to several years [Van- 
del, 1965; Hüppop, 1985]. According to the energyeconomy hypothesis, the adaptation of subterranean animals to low energy includes a reduction in pigments and eyes, infrequent reproduction, small brood size, reduced metabolism and growth rates, and increased longevity [Poulson, White, 1969; Howarth, 1983].

Most of specialized animals possess specific metabolism and organs storing food and resources. The crustacean hepatopancreas is the primary site for lipid digestion and metabolism [Chang, O'Connor, 1983; Gibson, Barker, 1979]. The lipid reserves in cavedwelling shrimps of the genus Troglocaris are stored extracellularly in specialized compartments of hepatopancreas, named oleospheres [Vogt, Strus, 1992, 1999], a fascinating adaptive mechanism to survive in the nutrient-poor hypogean environment. Well-developed oleospheres in T. anophthalmus allowing survival of shrimps without food for more than 2 years [Vogt, Strus, 1999]. At the same time, nothing is known about Troglocaris larval development and larva nutrition as only few females with eggs has been sampled in Balkans [Matjasic, 1958; Juberthie-Jupeau, 1969; Jugovic et al., 2015]. Moreover, the release of decapod larvae in the non-hypogean environment has been correlated to different environmental cycles [Morgan, Christy, 1994] that remain poorly studies in cave biotopes.

The stygobiotic atyid shrimp genus Troglocaris Dormitzer, 1853 currently includes six Caucasian species referring to the subgenus Xiphocaridinella Sadowsky, 1930 (according to WoRMS, 2017). Three species, Troglocaris (Xiphocaridinella) kutaissiana (Sadowsky, 1930) (the type species of the subgenus), Troglocaris (Xiphocaridinella) fagei Birštein, 1939 and Troglocaris (Xiphocaridinella) jusbaschjani Birštein, 1948, were currently re-described based on topotypic material [Marin, Sokolova, 2014; Marin, 2017] as well as a new species, Troglocaris (Xiphocaridinella) kumistavi Marin, 2017 was recently described from underground stream and lakes of Kumistavi (Prometheus) Cave, Tskaltubo, Imereti region, Western Georgia [Marin, 2017] based on morphological investigation and DNA analysis. Among the specimens of $T$. kumistavi collected in Kumistavi Cave several ovigerous females with eggs were sampled, representing the first described locality in Georgia where Caucasian Troglocaris shrimps were found breeding ("breeding pool") [Marin, 2017]. Previously, only non-ovigerous females of Troglocaris shrimps were found in Caucasian underground lakes and cave streams; probably they were washed out there from their underground "breeding pools" by flood water [Marin, Sokolova, 2014]. Herewith, we present a preliminary description of larvae of T. kumistavi and indications of the yolk lipid nutrition in larval development of Troglocaris as the first study of larval development of cave-dwelling atyid shrimp of this genus. Moreover, larvae of Troglocaris have never been observed even in natural cave reservoirs, neither in Balkan nor in Caucasus (I. Marin, pers. comm.).

\section{Material and methods}

Shrimps were collected in subterranean cave streams and lakes in Kumistavi Cave, Tskaltubo-Kumistavi $\left(42^{\circ} 22^{\prime} 35.8^{\prime \prime} \mathrm{N} 42^{\circ} 36^{\prime} 03.2^{\prime \prime} \mathrm{E}\right)$ by hand net in February 2016 that represent the period of larva hatching clearly correlated with the low water in cave reservoirs occurred in winter season, from December to March. This period in the winter season differs from the summer season (June-September) by a lower level of karst water in the cave. Collected ovigerous females were transported to the lab in the Moscow State University where 4 planktonic larvae successfully hatched. After hatching, all larvae were removed to à separate clean water 1-liter tank, and were photographed alive each 2 days and then fixed in 90\% ethanol for further morphological analysis. Fixed larvae are deposited in the collection of A.N. Severtzov Institute of Ecology and Evolution of Russian Academy of Sciences, Moscow, Russia (LEMMI). Species names and modern taxonomic position are given according to the international database WoRMS (World Register of Marine Species) and Marine Species Identification Portal. The study does not include endangered or protected species.

\section{Results and discussion}

Only 4 larvae were successfully reared and hatched under the temperature about $20-21^{\circ} \mathrm{C}$ in the water tank. It was impossible to assess the number of zoeal stages and examine zoeal morphology in details because we tried to keep all larvae alive. Detailed morphological description of larval stages will be the aim of our further study. However, it is possible to describe the development of T. kumistavi larvae as complete, but abbreviated and accelerated. Preliminary, we conclude that T. kumistavi possess 4 or 5 zoeal stage in their development showed in Figs 1, 2. At the same time, no exuviae were found in the tank where larvae of Troglocaris stayed during the study as well as it was impossible to select exact molting stages in their development. It is possible that the remains of the exuviae were eaten by larvae very quickly, before they were seen. Studied Troglocaris larvae possessed with thin soft (membranous) cuticle and, possibly, were able to grow appendages without molting. Non-feeding larvae are deprived of the opportunity to replenish the food resources and the absence of molting as well as the discharge of the exuvium seems to be a very valuable feature of their development and an excellent adaptation to the underground way of life. Freshly hatched larvae possessed with partly developed pereiopods and developed pleopods (Fig. 2a,b) used for swimming and skipping. They actively swam with tail fun up, they were not reacting to lighting (any phototaxis (positive or negative) was not detected) and did not show indication of feeding. Most of time of observation larvae moved randomly. Morphology of zoeal stage I (Fig. $2 a, b)$ is similar to the "abbreviated metamorphosis 


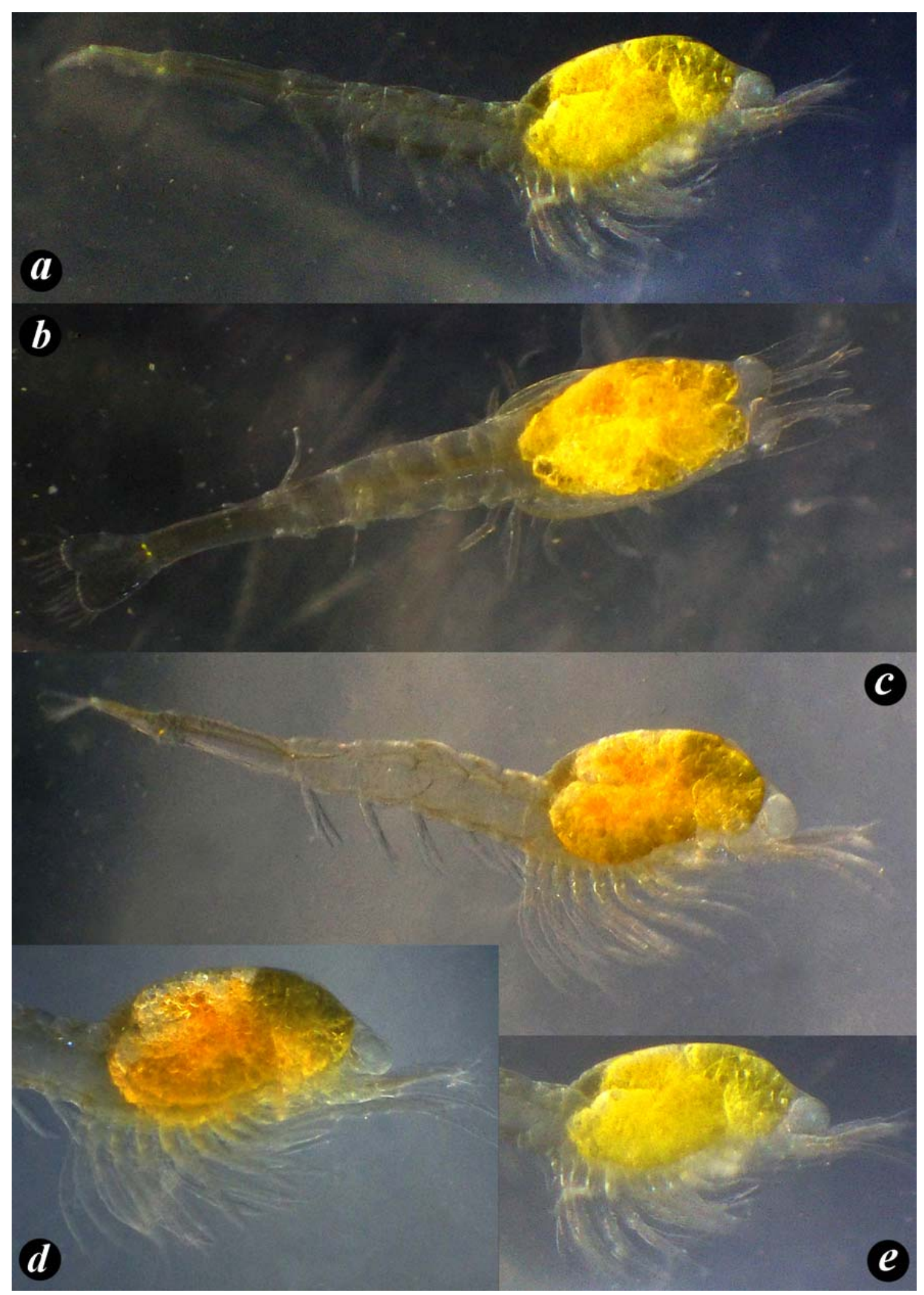

Fig. 1. Larval development of Troglocaris (Xiphocaridinella) kumistav Marin, 2017: $a, b, e-2$ days after hatching; $c, d-4$ days after hatching.

Рис. 1. Личиночное развитие Troglocaris (Xiphocaridinella) kumistavi Marin, 2017: a, b, e-2 дня после выхода из яйцевых оболочек; $c, d-4$ после выхода из яйцевых оболочек. 


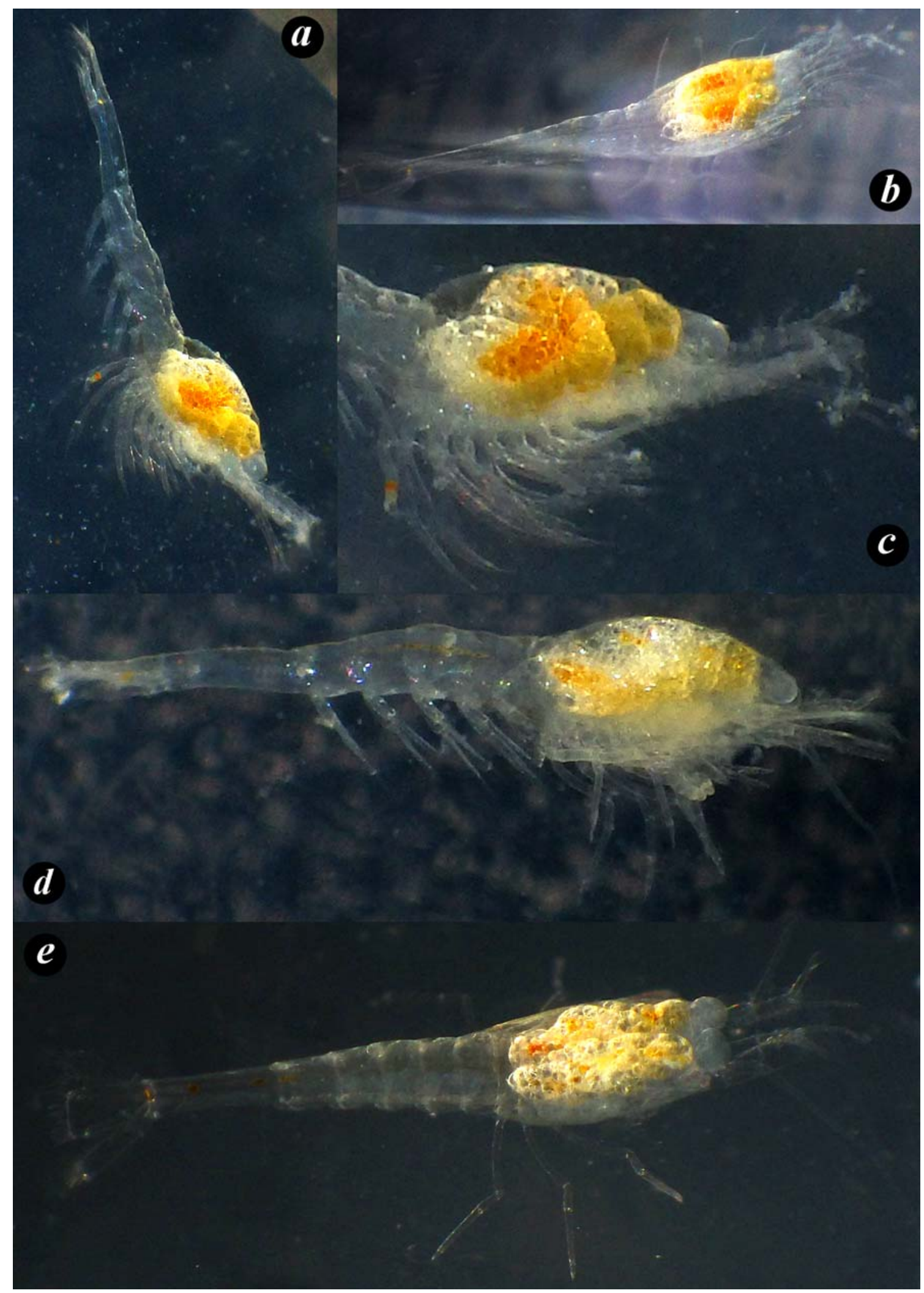

Fig. 2. Larval development of Troglocaris (Xiphocaridinella) kumistavi Marin, 2017: $a-c-6$ days after hatching; $d, e-8$ days after hatching.

Рис. 2. Личиночное развитие Troglocaris (Xiphocaridinella) kumistavi Marin, 2017: a-c - 6 после выхода из яйцевых оболочек; $d, e-8$ дней после выхода из яйцевых оболочек. 
type" reported by Glaister [1976]. Although abbreviated or direct development is described for larvae of Atyidae (for example, Caridina singhalensis (Benzi, De Silva, 1983) and could be suggested for cave-dwelling representatives of the family. The reduction in the number of moults and shortened larval life is probably characteristic for Troglocaris. In our experiment the water temperature was higher than in cave water reservoir (about $12-14{ }^{\circ} \mathrm{C}$ ) and we are unable to make such conclusion as the influence of temperature is clearly correlated with the time duration of each stage of cold water shrimps [Knowlton, 1974; Criales, Anger, 1986; Schultze, Anger, 1997]. Anyway, after just 8 days our larvae metamorphosed to fully functional postlarvae settled to the bottom of the tank (Fig. $2 d, e$ ). A visual decrease of yolk deposits was observed during the period of the development (Figs. 1,2) indicating this to be the only feeding resource of larvae. At the same time, such lipid yolk reserves are absent in adult Troglocaris shrimps, having only oleospheres in hepatopancreas. Larvae of hydrothermal vent shrimps of the genus Rimicaris Williams et Rona, 1986 (Crustacea: Decapoda: Alvinocarididae) [Pond et al., 1997] were also found to be rich in lipids absent in the adults. Pond et al. [1997] postulated that these lipid reserves were an adaptation to prolong the larval life need to find new biotopes or to survive unfavorable natural conditions.

Shokita [1981] and Hayashi \& Hamano [1984] suggested to divide all representatives of the family Atyidae into three groups based on egg size including the species with "small egg" species generally exhibiting extended development and "large egg" species exhibiting abbreviated or direct development. Moreover, species with direct development usually spend their entire life cycle in upland streams while extended larval developers tend to utilize marine or estuarine environmental resources for larval development [Walsh, 1993]. According to our preliminary investigation, T. kumistavi spending all lifecycle in closed freshwater cave reservoirs is referred to species with large lecitotrophic eggs (see Marin, 2017) and relatively small broods but possessing, on the other hand, relatively large planktonic larvae with 4-5 abbreviated stages characteristic for other representatives of the family Atyidae (see examples in Walsh, 1993). Probably, large yolk lipid larval reserves allow larvae to complete metamorphosis into benthic post-larva without feeding on planktonic organisms or suspended organic matter absent or highly defficient in cave reservoirs. Such combination of these two features of larval development and correlation of hatching time with the lowest water level additionally characterizes Troglocaris as relict estuarine or brackish water dwellers highly adapted to troglobiotic lifestyle in the hypogean aquatic habitats with slow or zero flow. It is very likely, that shrimps require subterranean water bodies with permanent and non-flowing water reservoirs for reproduction and larval development. Their finding in subterranean rivers or streams is evidently the result of their export/washing out from such permanent underground reservoirs (lakes).

\section{Acknowledgements}

The authors are grateful to Agniya Sokolova and Dmitry Palatov (A.N. Severtzov Institute of Ecology and Evolution of RAS, Moscow) for the sampling material in Georgia and join their thanks to the staff of Kumistavi (Prometheus) Cave, Tskaltubo-Kumistavi allowing sampling within the cave biotopes.

\section{References}

Barr T.C., Jr. 1968. Cave ecology and the evolution of troglobites // Evolutionary Biology. Vol.2. P.35-102.

Benzie J.A.H., De Silva P.K. 1983. The abbreviated larval development of Caridina singhalensis Ortmann, 1894 (Decapoda: Atyidae) endemic to Sri Lanka // Journal of Crustacean Biology. Vol.3. P.117-126.

Chang E.S., O'Connor J.D. 1983. Metabolism and transport of carbohydrates and lipids // Mantel L.H. (ed.). The biology of Crustacea. Academic Press, New York. Vol.5. P.263-287.

Gibson R., Barker P.L. 1979. The decapod hepatopancreas // Oceanography and Marine Biology - An Annual Review. Vol.17. P.285-316.

Criales M.M., Anger K. 1986. Experimental studies on the larval development of the shrimps Crangon crangon and C. allmanni // Helgolander Meeresuntersuchungen. Vol.40. P.241-265.

Glaister J.P. 1976. Postembryonic growth and development of Caridina nilotica aruensis Roux (Decapoda: Atyidae) reared in the laboratory // Australian Journal of Marine and Freshwater Research. Vol.27. P.263-278.

Hayashi K.-I., Hamano T. 1984. The complete larval development of Caridina japonica De Man (Decapoda, Caridea, Atyidae) reared in the laboratory // Zoological Science. Vol.1. P.571589.

Howarth F.G. 1983. Ecology of cave arthropods // Annual Review of Entomology. Vol.28. P.365-389.

Hüppop K. 1985. The role of metabolism in the evolution of cave animals // NSS Bulletin. Vol.47. P.136-146.

Juberthie-Jupeau L. 1969. Reproduction et mue chex les Decapodes souterrains due genre Troglocaris Dormitzer, 1853 // Fifth congres intemationaler du speleologie, Stuttgart. P.B32.-B32.2.

Jugovic J., Praprotnik E., Buzan E.V., Lužnik M. 2015. Estimating population size of the cave shrimp Troglocaris anophthalmus (Crustacea, Decapoda, Caridea) using mark-release-recapture data // Animal Biodiversity and Conservation. Vol.38. No.1. P.77-86.

Knowlton R.E. 1974. Larval developmental processes and controlling factors in decapod Crustacea, with emphasis on Caridea // Thalassia Jugoslavica. Vol.10. P.139-156.

Marin I.N. 2013. [Atlas of Decapod Crustaceans of Russia]. Moscow: KMK Scientific Press. 145 p. [in Russian with English abstract].

Marin I. 2017. Troglocaris (Xiphocaridinella) kumistavi sp. nov., a new species of stygobiotic atyid shrimp (Crustacea: Decapoda: Atyidae) from Kumistavi Cave, Imereti, Western Georgia, Caucasus // Zootaxa. Vol.4311. No.4.P.576-588.

Marin I., Sokolova A. 2014. Redescription of the stygobiotic shrimp Troglocaris (Xiphocaridinella) jusbaschjani Birštein, 1948 (Decapoda: Caridea: Atyidae) from Agura River, Sochi, Russia, with remarks on other representatives of the genus from Caucasus // Zootaxa. Vol.3754. No.3. P.277-298.

Matjasic J. 1958 Postembrionalni razvoj jamske kozice Troglocaris // Biološki vestnik.Vol.6. P.76-92.

Morgan S.G., Christy J.H. 1995. Adaptive significance of the timing of larval release by crabs // American Naturalist. Vol.145. P.457-479.

Pond D., Dixon D., Sargent J. 1997. Wax-ester reserves facilitate dispersal of hydrothermal vent shrimps // Marine Ecology Progress Series. Vol.146. P.289-290.

Poulson T.L., White W.B. 1969. The cave environment // Science. Vol.165. P.971-981. 
Schultze K., Anger K. 1997. Larval growth patterns in the aesop shrimp Pandalus montagu // Journal of Crustacean Biology. Vol.17. P.472-479.

Shokita S. 1981. Life-history of the family Atyidae (Decapoda, Caridea) // Aquabiology. Vol.12. P.15-23.

Vandel A. 1965. Biospeleology: the Biology of Cavernicolous Animals. Oxford: Pergamon Press. 524p.

Vogt G., Strus J. 1992. Oleospheres of the cave-dwelling shrimp Troglocaris schmidtii: a unique mode of extracellular lipid storage // Journal of Morphology. Vol.211. P.31-39.
Vogt G., Strus J. 1999. Hypogean life-style fuelled by oil // Naturwissenschaften. Vol.86. P.43-45.

Walsh C.J. 1993. Larval Development of Paratya australiensis Kemp, 1917 (Decapoda: Caridea: Atyidae), Reared in the Laboratory, with Comparisons of Fecundity and Egg and Larval Size between Estuarine and Riverine Environments // Journal of Crustacean Biology. Vol.13. No.3. P.456-480.

Responsible editor V.A. Spiridonov 